\title{
The vertical distribution of epiphytic orchids on Schima wallichii trees in a montane forest in West Java, Indonesia
}

\author{
INDRA FARDHANI", TAKESHI TORIMARU, HIROMITSU KISANUKI \\ Graduated School of Bioresources Mie University. Mie Prefecture, Japan 514-0001, `email: indrafardhani@gmail.com.
}

Manuscript received: 2 October 2019. Revision accepted: 27 December 2019

\begin{abstract}
Fardhani I, Torimaru T, Kisanuki H. 2020. The vertical distribution of epiphytic orchids on Schima wallichii trees in a montane forest in West Java, Indonesia. Biodiversitas 21: 290-298. Schima wallichii Choisy. is a mostly montane species native to the island of Java; it grows on degraded land areas and is widely used for forest restoration. We studied the vertical distribution of epiphytic orchids on these trees in montane forest on Mt. Sanggara, West Java, Indonesia. To this end, $40 \mathrm{~S}$. wallichii trees with diameter at breast height $(\mathrm{DBH})>20 \mathrm{~cm}$ were chosen haphazardly and their epiphytic orchids were identified The diameter and height of each host tree were measured. The position of each epiphytic orchid on each host tree was allocated to one of five zones using Johansson's method. In total, 39 epiphytic orchid species were identified on 40 host trees at the study site. There was no significant difference in orchid abundance or species richness between crown zones. However, there were significant differences in orchid abundance and species richness between trunks and crowns. Host tree size $(\mathrm{DBH})$ and the number of branches were positively correlated with orchid abundance and species richness. The numbers of orchids and other epiphytic plants were positively correlated in the mid-crown and outer-crown. $S$. wallichii trees are essential for the epiphytic orchid community because they produce many branches that are suitable for colonization.
\end{abstract}

Keywords: Epiphytic plant, Java, orchid, Schima wallichii, vertical distribution

\section{INTRODUCTION}

Vascular epiphyte plants composed up to one half of the total species richness in the tropical forest which make them as one of the vital component (Flores-Palacios and Garcia-Franco 2006). Among the plant families, Orchidaceae is composed of the epiphyte species with nearly $70 \%$ of the total described species (Gravendeel et al. 2004). The difficulty to access canopy area becomes the greatest obstacle to understand epiphytic orchid in the South-East Asia region, compare to the Neotropic region (O'Malley 2009). Most previous studies concern vascular epiphytes in general, whilst studies of epiphytic orchids are limited (ter Steege and Cornelissen 1989, Zotz and Hietz 2001, Flores-Palacios and Garcia-Franco 2006, Krömer et al. 2007, Sanger and Kirkpatrik 2017).

Epiphytic orchids depend on the availability of host trees and are greatly affected by microclimate (Hietz et al. 2006, Mondragon et al. 2015). Several authors have described species composition and richness of non-vascular (Sporn et al. 2009) and vascular epiphytes at different heights on trees (ter Steege and Cornelissen 1989, Krömer et al. 2007). Zonal variation in the structural attributes of the host tree can influence the distribution of epiphytes because it provides a variety of microclimates (Sanger and Kirkpatrick 2017): light, humidity, and temperature differ with the height of a tree (Wagner et al. 2013, Sanger and Kirkpatrick 2015). For example, the canopy generally offers more light for epiphytes compared to the dark understory (Nieder et al. 2001).

Several characteristics of the host tree will influence the orchid community. Previous studies have shown that branch size and inclination affect the number of epiphytes (Garth 1964, Rudolph et al. 1998, Nieder et al. 2001). However, the effect of number of branches on the epiphytic orchid community present on a host tree remains unclear. Number of host tree branches may influence the community because branches provide epiphytes with places to attach. In addition, tree size correlates positively with epiphytic richness (Flores-Palacios and Garcia Franco 2006, Taylor and Burns 2015). Furthermore, epiphytic orchid species inhabiting a host tree may exhibit differences in vertical distribution among the layers from trunk to crown. The crown offers its occupants a varied microclimatic and nutrient regime and this variety undoubtedly contributes to arboreal plant diversity including epiphytic orchids (Nadkarni et al. 2001). Thus, differences in the depth of crown layers may also affect the epiphytic orchid communities that inhabit the crown because its depth is strongly and negatively related to light availability (Gower and Norman 1991, Coble et al. 2014).

In addition, epiphytic orchids commonly share habitat with other vascular epiphytic plants. Although the densities of vascular epiphytes are frequently very low (Zotz 2016), it is important to understand the effect of other vascular epiphytes on the epiphytic orchid community because of competition between them may have an impact of the persistence of epiphytic orchid species (Taylor and Burns 2015).

Schima wallichii Choisy (Theaceae) is an evergreen tree species found across subtropical and tropical zones at altitudes from 5 to $3300 \mathrm{~m}$ (Bloembergen 1952) in the Himalayas, East Asia, and Southeast Asia (Tuyama 1989). S. wallichii is a common and dominant tree species in 
several tropical montane forests in West Java Province, for example, on Mt. Gede, Mt. Pangrango and Mt. Sanggara (van Steenis 1972, Yamada 1975, Muhamad et al. 2014, Fardhani et al. 2015). This species grows up to $45 \mathrm{~m}$ in height; its cylindrical trunk attains a diameter up to $250 \mathrm{~cm}$, with steep buttresses, rarely up to $1.8 \mathrm{~m}$ high; the bark surface is ruggedly cracked into small, thick, angular pieces (Orwa et al. 2009). Several authors mention S. wallichii as a host for epiphytic plants such as bryophytes, orchids, and ferns because it has large canopy for epiphytes to attach (Setyawan 2000; Marsusi et al. 2001; Puspitaningtyas 2007).

Differences in epiphyte microsites on a host tree are present at different spatial scales, including on a single branch, between branches at different heights and between trees with different architecture (Nadkarni et al. 2001). Therefore, we propose the hypothesis that factors such as host tree size, number of branches, crown depth of a host tree and the presence of other vascular epiphytes on a host may influence the epiphytic orchid community on $S$. wallichii trees. In order to test this hypothesis, we examined the following questions: (i) are there differences in epiphytic orchid abundance (the number of individuals) and species richness (the number of species) at different heights on host trees?; (ii) are epiphytic orchid abundance and species richness positively affected by tree size, number of branches and crown depth of the host?; and (iii) is there competition between epiphytic orchids and other vascular epiphytic plants within the same height layer of a host tree?

\section{MATERIALS AND METHODS}

\section{Study area}

The study site is located in the Legok Jero area (6 $\left.6^{\circ} 48^{\prime} 41 \mathrm{~S} ; 1^{\circ} 7^{\circ} 44^{\prime} 43 \mathrm{E}\right)$ of Mt. Sanggara (1903 m a.s.l), West Bandung Regency, West Java Province, Indonesia (Figure 1). The altitude at the study site is between $1656 \mathrm{~m}$ and $1724 \mathrm{~m}$ a.s.l on western side of the mount. Annual rainfall is $3047 \mathrm{~mm}$ and average annual temperature is $20.0^{\circ} \mathrm{C}$ at Lembang, which is located about $20 \mathrm{~km}$ from the study site (id.climate-data.org 2018). The forest is dominated by evergreen broadleaved $S$. wallichii trees, along with Sloanea sigun, Schefflera rugosa, and Castanopsis acuminatissima. The area is part of a protected forest managed by a government-owned forestry company. Much of the forest floor had been cleared for coffee plantation under the shade of the large trees as a part of community development program (Fardhani et al. 2015).

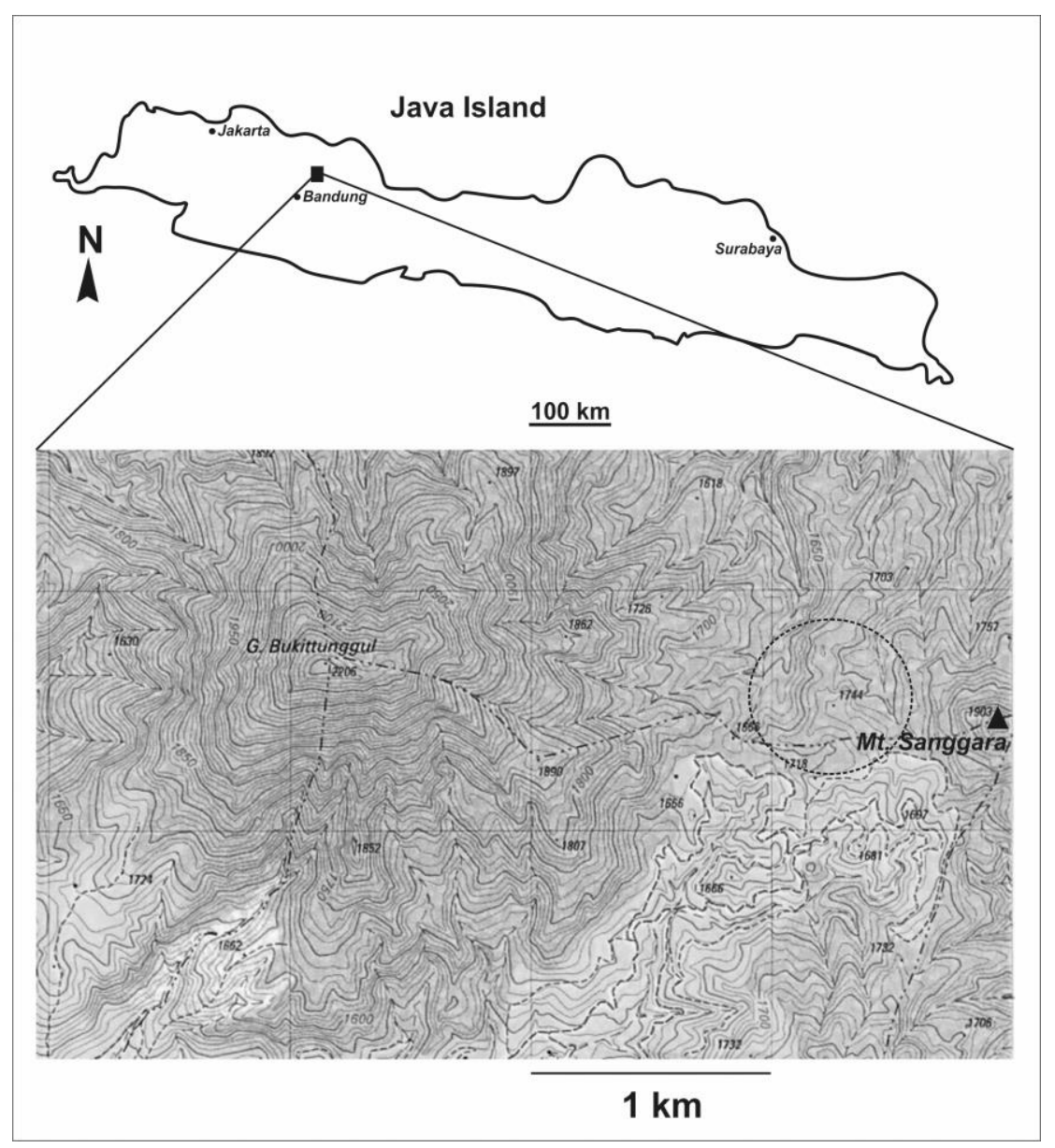

Figure 1. Map of the Legok Jero area, Mount Sanggara, West Java Province. The study area is marked with the dashed circle and the distance between contours is 12.5 meters (modified map of Bakosurtanal (2001) 


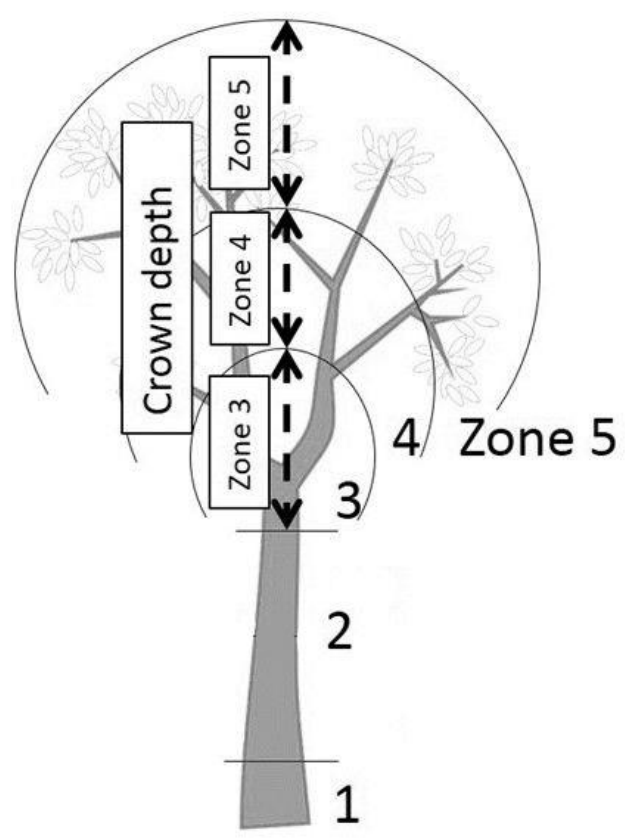

Figure 2 Illustration of the Johansson zones (zone 1: basal part of the trunk, zone 2: trunk, zone 3: inner crown, zone 4: mid-crown, and zone 5: outer-crown) with modification after Johansson (1974)

\section{Procedures}

We haphazardly selected $40 \mathrm{~S}$. wallichii trees with a diameter at breast height (DBH) more than $20 \mathrm{~cm}(\mathrm{DBH}$ : average $58.5 \mathrm{~cm}$, maximum $107.3 \mathrm{~cm}$, minimum $27.3 \mathrm{~cm}$ ). There was a distance of at least $20 \mathrm{~m}$ between trees.

The numbers of individual epiphytic orchids and species growing on the host trees were recorded using both ground-based observation (Taylor and Burns 2015) and the single rope technique (Flores-Palacios and Garcia-Franco 2006). Both methods were used because we were able to estimate the presence of epiphytes more accurately using the single rope technique, but ground-based observation is safer and faster (Flores-Palacios and Garcia-Franco 2001). We only used single rope technique on 5 selected host trees which considered safe and accessible. We used grownbased observation for the rest of host trees.

In an attempt to compare the difference in the vertical distribution of epiphytic orchids, their occurrence on each host tree was allocated to one of five vertical zones, according to Johansson (1974, Figure 2): basal part of the trunk (zone 1), trunk (zone 2), inner crown (zone 3), midcrown (zone 4), and outer-crown (zone 5). Zone 1 refers to basal part of the trunk from soil up to one or two meters above; zone 2 is above the zone 1 up to the first ramification; zone 3 covers the basal part of the large branches (1/3 of the total length of the branch); zone 4 refers the middle part of the large branches (1/3 of the total length of the branch), and zone 5 is the outer part of the large branches (1/3 of the total length of the branch). Johansson zone 1 was omitted from the analysis because no epiphytic orchid was found there. Each orchid specimen was photographed or sampled for later identification according to Comber (1990). Clumped or creeping orchids were counted as one individual.

Host tree diameter and height were measured with diameter tape and a tree altimeter (Haglof® Vertex III), respectively. The number of branches in each zone of each host tree was counted (Number of branches: average 146, maximum 252, minimum 36). The minimum diameter of branches included in the analysis was $1 \mathrm{~cm}$. Twigs with a diameter of more than $1 \mathrm{~cm}$ were considered to be branches and included in the count. The crown depth of Johansson zones 3, 4, and 5 were also measured. The term 'crown depth' in this study refers to the highest point of each Johansson zone 3, 4 and 5 (crown zone) to the highest point of the next lower zone. For example, the crown depth of zone 3 is the distance between its highest point and that of zone 2 (Figure 2). The numbers of all other vascular epiphytes (ferns, monocots, and dicots) were also recorded for each zone to allow us to investigate the relation between epiphytic orchid and other vascular epiphytic plants community. All data were collected between April 9th and 18th, 2017.

\section{Data analysis}

To test whether the observed abundance of each epiphytic orchid species differs from the expected abundance in each Johansson zone, a Chi-squared test was conducted for species with more than 20 individuals across the 40 host trees. Expected abundance of each orchid species in a particular Johansson zone was calculated based on the proportional abundance in each Johansson zone in the whole community using the following equation:

$$
\text { Expected abundance }=\frac{b \times c}{d} \text {. }
$$

Where: $b$ is the total abundance of an epiphytic orchid species, $c$ is the total abundance of all species in a specific Johansson zone, and $d$ is the total abundance of all epiphytic orchid species.

One-way ANOVA followed by Scheffe's multiple comparison test was conducted to investigate differences in orchid abundance and species richness within each Johansson zone for host trees with more than 25 individual epiphytic orchids. A generalized linear model (GLM) was constructed to determine which factors affect epiphytic orchid abundance and species richness (Bolker et al. 2009). The explanatory variables included were DBH, number of branches in crown zones (zone 3, 4, and 5) and crown depth of the host tree. GLM with a Poisson error distribution and a logarithmic link function was used since the factor generally satisfied the Poisson error distribution as a count variable (Bolker et al. 2009, Kwon et al. 2018). Models were ranked and those with the lowest AIC (Akaike's Information Criterion) value were selected. A Wald test was conducted to determine the significance of regression coefficients for each model (Bolker et al. 2009, Ives 2015). To avoid multicollinearity, we screened covariates using the Variable Inflation Factor (VIF) and 
removed any variable with $\mathrm{VIF}>5$ for moderate multicollinearity (Bagheri and Midi 2009, Mansfield and Helms 1982). To understand the interaction between communities, Pearson's correlation coefficients were calculated between orchid and vascular epiphyte abundance in each zone. All of the statistical analyses were performed using $\mathrm{R}$ version 3.3.0 (R Development Core Team 2016) in RStudio Version 1.0.136 (RStudio Team 2016).

\section{RESULTS AND DISCUSSION}

The results of the present study were shown (i) vertical distribution of epiphytic orchids on S. wallichii, (ii) factors affecting species richness and abundance of epiphytic orchids, and (iii) correlation between epiphytic orchids and other vascular epiphytes abundance on $S$. wallichii.

\section{Epiphytic orchid vertical distribution}

In total, 39 epiphytic orchid species were identified on 40 host trees (Table 1). Of these, two species -Ceratostylis backeri, J.J.Sm. and Ceratostylis capitata Zoll. \& Moritzi.are endemic to Java. Only two species - Coelogyne miniata (B1.) and Bulbophyllum salaccense Rchb.f.- were found in every Johansson zone. Out of 39 species were observed, only 17 species were sorted to perform further distribution pattern analysis. After the analysis, only four species $(C$. miniata, Eria multiflora (B1.) Lindl., Dendrobium sp. 1, and Bulbophyllum stelis J.J.sm.) exhibited a similar distribution pattern as all of them mostly distributed in crown zones than the trunk zone. Sixteen out of 17 species inhabited every layer of the crown (zones 3, 4, and 5). Five species (Schoenorchis juncifolia Bl. ex Reinw., B salaccense, $C$. capitata, Bulbophyllum ovalivolium (B1.) Lindl., and Appendicula angustifolia Bl.) grew significantly more abundant on the trunk than expected. On the other hand, four species (Pholidota globossa (B1.) Lindl., Pholidota carnea (B1.) Lindl., C. backeri, and Dendrochillum cornutum B1.) grew on outer-crown (zone 5) significantly more abundant than expected (Table 1).

The distribution of orchid individuals on Schima wallichii trees differed between species. Specifically, some species such as $P$. globossa, C. trinervis, and D. cornutum were found only in the crown, while many others were present both on the trunk and in the crown (Table 1). Among vascular epiphytes, habitat specialization does sometimes occur (Krömer et al. 2007). A study in the Bolivian Andes, however, revealed that $50-80 \%$ of vascular epiphytic species occur in most height zones and very few epiphytes are limited to one zone (Krömer et al. 2007). We could show that most of epiphytic orchid species are not specialized to a certain zone of $S$. wallichii trees, but are distributed in almost the entire tree, although most individuals are found in the crown.

There were significant differences in orchid abundance and species richness between the trunk (zone 2) and crown (zones 3, 4, and 5) (Table 2). The crown supported more epiphytic orchid species and individuals than the trunk.
However, there was no significant difference in orchid abundance and species richness between crown zones (Table 2).

According to previous research, the mid-crown zone (zone 4) supports the highest abundance and species richness of vascular epiphytes (ter Steege and Cornelissen 1989, Nieder et al. 2001). Orchids also tend to colonize the mid-crown zone, where microclimatic conditions and host characteristics are probably most favorable for their survival in a tropical dry forest (de la Rosa-Manzano et al. 2014). However, in this study, such phenomena were not observed. The differences were not significant for either orchid abundance or species richness between the three zones in the crown (Table 2). Therefore, all crown zones of S. wallichii appear to provide similar microclimatic conditions for the epiphytic orchids inhabiting this tree species in the tropical montane forest of West Java.

Orchids can adapt to the scarce resources available in the higher zone of host trees (ter Steege and Cornelissen 1989, Krömer et al. 2007) by obtaining nutrients from stem flow and decaying detritus (Awasthi et al. 1995). Epiphytic orchids have special adaptations to drought stress in canopy such as pseudobulbs and succulence (Benzing 1990). We observed that most of the epiphytic orchid species growing in the outer-crown had visible pseudobulbs, for example in C. miniata, P. globossa, P. carnea, and D. cornutum, or had succulent leaves and stems for water storage, as in $C$. backeri. On the other hand, epiphytic orchids that has significant abundant on the trunk had small pseudobulbs, as exhibited by $B$. salaccense and $B$. ovalifolium, or small stems without pseudobulbs, for example, A. angustifolia (Table 1). We speculate epiphytic orchid species that grow on trunk are often found with small or without pseudobulb to make it easier to attach to a vertical trunk. It is noteworthy that the size difference on both pseudobulb and whole plant size between epiphytic orchids growing on trunks and in crowns has not been reported previously. Further research about the relation between pseudobulb size and vertical distribution of epiphytic orchid in a host tree may explain this phenomenon.

\section{Factors affecting epiphytic orchid abundance and species richness}

GLM analysis of factors that affect orchid abundance and species richness was conducted for the whole crown with no separation of the Johansson zones (3, 4, and 5) because there was no significant difference in orchid abundance and species richness between these zones (Table 2). No multicollinearity between explanatory variables was found (VIF < 5) indicating no correlation among factors so that all variables could be included in the GLMs. The five models for orchid abundance with the lowest AIC values are shown in Table 3. Four of these models suggested a significant positive effect of host tree $\mathrm{DBH}$ on orchid abundance. Three models suggested a positive effect of number of branches on orchid abundance. Crown depth had a significant positive effect on orchid abundance in some models. 
Table 1. Species composition of epiphytic orchids on 40 Schima wallichii trees in each Johansson zone

\begin{tabular}{|c|c|c|c|c|c|c|c|}
\hline \multirow{2}{*}{ Orchid Species } & \multirow{2}{*}{$\begin{array}{l}\text { Pseudo- } \\
\text { bulb type }\end{array}$} & \multicolumn{4}{|c|}{ Abundance } & \multirow{2}{*}{ Total } & \multirow{2}{*}{$p$ value } \\
\hline & & Zone 2 & Zone 3 & Zone 4 & Zone 5 & & \\
\hline Coelogyne miniata (Bl.) Lindl. & $\mathrm{vp}$ & $21(23)$ & $114(105)$ & $141(146)$ & $132(134)$ & 408 & 0.798 \\
\hline Bulbophyllum flavescens (B1.) Lindl. & np & $4(15)$ & $78(67)$ & $94(93)$ & $85(86)$ & 261 & 0.026 \\
\hline Eria multiflora (B1.) Lindl. & $\mathrm{np}$ & $13(11)$ & $69(52)$ & $60(72)$ & $59(66)$ & 201 & 0.052 \\
\hline Pholidota globossa (B1.) Lindl. & $\mathrm{vp}$ & $1(7)$ & $1(34)$ & $55(47)$ & $74(43)$ & 131 & $<0.001$ \\
\hline Pholidota carnea (B1.) Lindl. & $\mathrm{vp}$ & $4(6)$ & $17(26)$ & $26(36)$ & $54(33)$ & 101 & $<0.001$ \\
\hline Schoenorchis juncifolia Bl. ex Reinw, & np & $7(4)$ & $27(18)$ & $19(25)$ & $16(23)$ & 69 & 0.019 \\
\hline Ceratostylis backeri J.J.Sm.* & np & $2(4)$ & $8(17)$ & $29(24)$ & $29(22)$ & 68 & 0.034 \\
\hline Coelogyne trinervis Lindl. & $\mathrm{vp}$ & $0(3)$ & $4(15)$ & $35(21)$ & $20(19)$ & 59 & $<0.001$ \\
\hline Dendrochillum cornutum $\mathrm{Bl}$. & $\mathrm{vp}$ & $0(3)$ & $16(14)$ & $13(19)$ & $25(18)$ & 54 & 0.042 \\
\hline Trichotosia annulate $\mathrm{Bl}$. & np & $2(3)$ & $19(13)$ & $28(18)$ & $2(17)$ & 51 & $<0.001$ \\
\hline Dendrobium sp. 1 & np & $2(3)$ & $13(12)$ & $23(17)$ & $10(16)$ & 48 & 0.234 \\
\hline Dendrochillum simile $\mathrm{Bl}$. & $\mathrm{vp}$ & $4(2)$ & $7(7)$ & $15(10)$ & $2(9)$ & 28 & 0.009 \\
\hline Bulbophyllum salaccense Rchb.f. & snp & $7(2)$ & $5(7)$ & $10(10)$ & $5(9)$ & 27 & $<0.001$ \\
\hline Ceratostylis capitata Zoll. \& Moritzi.* & $\mathrm{np}$ & $7(1)$ & $8(7)$ & $9(9)$ & $2(9)$ & 26 & $<0.001$ \\
\hline Bulbophyllum ovalifolium (B1.) Lindl. & svp & $4(1)$ & $5(6)$ & $13(9)$ & $3(8)$ & 25 & 0.020 \\
\hline Bulbophyllum stelis J.J.sm. & $\mathrm{np}$ & $2(1)$ & $3(6)$ & $10(9)$ & $9(8)$ & 24 & 0.518 \\
\hline Appendicula angustifolia $\mathrm{Bl}$. & $\mathrm{np}$ & $6(1)$ & $15(5)$ & $0(8)$ & $0(7)$ & 21 & $<0.001$ \\
\hline Ceratochillus biglandulosus $\mathrm{B} 1$. & $\mathrm{np}$ & 0 & 0 & 8 & 7 & 15 & \\
\hline Eria acuminata (B1.) Lindl. & $\ln p$ & 0 & 2 & 12 & 0 & 14 & \\
\hline Flickingeria angustifolia (B1.) A.D. Hawkes. & $\mathrm{vp}$ & 0 & 2 & 2 & 7 & 11 & \\
\hline Bulbophyllum absconditum J.J.Sm. & svp & 0 & 0 & 7 & 3 & 10 & \\
\hline Dendrobium heterocarpum Wall. ex Lindl. & $\mathrm{np}$ & 1 & 6 & 0 & 2 & 9 & \\
\hline Oberonia padangensis Schltr. & np & 1 & 8 & 0 & 0 & 9 & \\
\hline Eria sp. 1 & $\mathrm{vp}$ & 2 & 0 & 0 & 5 & 7 & \\
\hline Phreatia secunda (B1.) Lindl. & np & 0 & 0 & 0 & 7 & 7 & \\
\hline Ceratostylis sp. 1 & $\mathrm{np}$ & 0 & 1 & 1 & 4 & 6 & \\
\hline Eria flavescens (Bl.) Lindl. & $\mathrm{vp}$ & 2 & 2 & 2 & 0 & 6 & \\
\hline Eria lamonganensis Rchb.f & $\mathrm{vp}$ & 0 & 0 & 3 & 3 & 6 & \\
\hline Flickingeria sp. 1 & $\mathrm{vp}$ & 2 & 2 & 2 & 0 & 6 & \\
\hline Liparis pallida (B1.) Lindl. & $\mathrm{vp}$ & 3 & 3 & 0 & 0 & 6 & \\
\hline Bulbophyllum tjadasmalangensis J.J.Sm. & svp & 2 & 3 & 0 & 0 & 5 & \\
\hline Flickingeria sp. 2 & $\mathrm{vp}$ & 0 & 2 & 1 & 0 & 3 & \\
\hline Oberonia anceps Lindl. & $\mathrm{np}$ & 0 & 0 & 0 & 3 & 3 & \\
\hline Bulbophyllum sp. 1 & $\mathrm{vp}$ & 0 & 1 & 0 & 0 & 1 & \\
\hline Bulbophyllum sp. 2 & $\mathrm{vp}$ & 0 & 1 & 0 & 0 & 1 & \\
\hline Ceratostylis sp. 2 & np & 0 & 1 & 0 & 0 & 1 & \\
\hline Cleisostoma javanicum (B1.) Garay. & np & 0 & 0 & 0 & 1 & 1 & \\
\hline Dendrobium sp. 2 & np & 0 & 0 & 0 & 1 & 1 & \\
\hline Dendrobium sp. 3 & $\mathrm{np}$ & 0 & 1 & 0 & 0 & 1 & \\
\hline Total & & 99 & 444 & 618 & 570 & 1731 & \\
\hline
\end{tabular}

Note: An asterisk (*) indicates Java Island endemic species (Comber 1990). Expected abundances are shown in parentheses. Differences in number of each species from the total number were tested with a $\chi^{2}$ test only for species with more than 20 individuals across the 40 host trees. Pseudobulb type: vp visible pseudobulb, svp small but visible pseudobulb, snp small and not visible pseudobulb, np no pseudobulb, lnp large but not visible pseudobulb

Table 2. Average abundance and species richness of epiphytic orchids in each zone of Schima wallichii trees in which more than 20 individual epiphytic orchids were present.

\begin{tabular}{lccc}
\hline $\begin{array}{l}\text { Johansson } \\
\text { zone }\end{array}$ & n & $\begin{array}{c}\text { Average abundance } \\
\pm \text { S.D. }\end{array}$ & $\begin{array}{c}\text { Average species } \\
\text { richness } \pm \text { S.D. }\end{array}$ \\
\hline 2 & 34 & $2.6 \pm 4.8^{\mathrm{a}}$ & $1.3 \pm 1.8^{\mathrm{a}}$ \\
3 & 34 & $12.6 \pm 8.4^{\mathrm{b}}$ & $4.1 \pm 2.1^{\mathrm{b}}$ \\
4 & 34 & $17.8 \pm 13.0^{\mathrm{b}}$ & $4.7 \pm 2.4^{\mathrm{b}}$ \\
5 & 34 & $16.4 \pm 10.5^{\mathrm{b}}$ & $4.4 \pm 2.0^{\mathrm{b}}$ \\
\hline
\end{tabular}

Note: n: number of trees. Different letters indicate significant differences in the average value between the Johansson zones (one-way ANOVA with Scheffe's multiple comparisons, $p<0.05$ ).
For orchid species richness, the five models with the lowest AIC values are shown in Table 4. Two models suggested a significant positive effect of host tree DBH and number of branches on species richness. Based on this result, crown depth did not significantly affect epiphytic orchid species richness.

The tree size (DBH) of $S$. wallichii trees had a positive effect on abundance (Table 3 ) and species richness (Table 4) of epiphytic orchids: larger trees hosted more orchid individuals and species. 
Table 3. Coefficients of five generalized linear models with the lowest AIC values for epiphytic orchid abundance in the crown layer (zones 3, 4, and 5) of Schima wallichii trees

\begin{tabular}{|c|c|c|c|c|c|c|c|}
\hline \multirow{2}{*}{$\begin{array}{l}\text { Model for epiphytic orchid } \\
\text { abundance }\end{array}$} & \multirow{2}{*}{$\Delta \mathbf{A I C}$} & \multicolumn{6}{|c|}{ Coefficient } \\
\hline & & Host DI & & Number o & es (No) & Crown d & \\
\hline 1 & 0.00 & 0.0147 & $* * *$ & 0.0025 & $* * *$ & & \\
\hline 2 & 2.00 & 0.0148 & $* * *$ & 0.0025 & $* * *$ & -0.0004 & ns \\
\hline 3 & 25.0 & 0.0172 & *** & & & & \\
\hline 4 & 26.3 & 0.0185 & **** & & & -0.0052 & ns \\
\hline 5 & 51.9 & & & 0.0036 & **** & 0.0319 & **** \\
\hline
\end{tabular}

Note: $* * * \mathrm{p}<0.001, \mathrm{~ns} \mathrm{p} \geq 0.05$

Table 4. Coefficients of five generalized linear models with the lowest AIC values for epiphytic orchid species richness in the crown layer (zones 3, 4, and 5) of Schima wallichii trees

\begin{tabular}{|c|c|c|c|c|c|c|c|}
\hline \multirow{2}{*}{$\begin{array}{l}\text { Model for epiphytic orchid } \\
\text { species richness }\end{array}$} & \multirow{2}{*}{$\Delta \mathrm{AIC}$} & \multicolumn{6}{|c|}{ Coefficient } \\
\hline & & \multicolumn{2}{|c|}{ Host DBH (cm) } & \multicolumn{2}{|c|}{ Number of branches (No) } & \multicolumn{2}{|c|}{ Crown depth (m) } \\
\hline 1 & 0.00 & 0.0072 & $*$ & 0.0021 & ns & & \\
\hline 2 & 1.41 & 0.0094 & ** & & & & \\
\hline 3 & 1.69 & & & 0.0026 & * & 0.0170 & ns \\
\hline 4 & 1.96 & 0.0065 & $\mathrm{~ns}$ & 0.0021 & ns & 0.0027 & ns \\
\hline 5 & 2.77 & & & 0.0030 & $* *$ & & \\
\hline
\end{tabular}

Note: $* * p<0.01, * \mathrm{p}<0.05, \mathrm{~ns} \mathrm{p} \geq 0.05$

Host tree size is one of the main factors influencing vascular epiphyte richness (Hirata et al. 2008) because tree size determines the number of vertical microhabitats inside the canopy (Flores-Palacios and Garcia-Franco 2006). Larger trees accumulate epiphytic species faster than smaller trees, once the first epiphytes have established (Taylor and Burns 2015). This suggests that at some point in ontogeny, branches become ideal, horizontal growing platforms to withstand large epiphyte communities compares with the smaller trees (Taylor and Burns 2015). Because epiphytes tend to accumulate on larger and older host trees, in general, the diversity and abundance of epiphytes are therefore positively correlated with the successional stage of a forest (Nieder et al. 2001). Furthermore, large-diameter trees are also important to maintain full ecosystem function (Lutz et al. 2018). Similar phenomena were observed at the study site. Larger sized and deeper crowned $S$. wallichii trees tended to host more abundant and a greater variety of epiphytic orchid species compared with the smaller and shallower crowned ones. Hence, conservation of $S$. wallichii trees that are large and have a deep crown would lead to the conservation of various species of epiphytic orchids and also maintain full ecosystem function in the tropical montane forest of West Java.

The number of host tree branches in crown zones had a positive effect on epiphytic orchid abundance (Table 3). This is a new insight added to previous information on the effect of branches of the host tree on vascular epiphyte abundance. According to the study by Nieder et al. (2001), branch size correlates with epiphytic plant abundance as larger branches offer suitable attachment sites. Trees lacking large branches due to their branching pattern are considered poor hosts for epiphytes (Garth 1964). Besides the size, branch inclination is inversely correlated to epiphyte abundance, including orchids (Rudolph et al. 1998). Horizontal branches support epiphyte communities because they allow the accumulation of crown soil as a critical water source (Nadkarni and Matelson 1991, Enloe et al. 2006, Taylor and Burns 2015). From our observations at the study site, emergent $S$. wallichii trees had almost branchless tall cylindrical trunks up to about 20 meters and had dense crowns with numerous branches (146 on average). We observed that many branches were almost horizontal, which would make it easy for epiphytic orchids to attach and colonize. However, we found that, along with the branch size and inclination, epiphytic orchid abundance is also affected by the number of branches on a host tree.

Orchid species richness was not affected by crown depth (zones 3, 4, and 5) (Table 4). According to Nieder and Zotz (1998), Johansson's zonation does not reflect height and each host tree may have different zone heights according to its structure. The same zones on different host trees might be located in different strata of the forest. At the study site, short-crowned trees were able to host just as many orchid species as long-crowned trees if they had numerous branches. For orchid abundance, only one model suggested a significant positive effect of crown depth (Table 3). Only certain species of orchids, such as $C$. miniata and $B$. flavescens, could attach to the vertical branches in the crown because these species have sympodial growth type and colonize form that makes them often easily attached to vertical branches. Crown depth did not exert a significant effect on orchid species richness: our observations suggest that, in the crown zones, most epiphytic orchid species root on fairly horizontal branches rather than on more vertical branches. 
Correlation between epiphytic orchids and other vascular epiphytes abundance on Schima wallichii

No correlation between number of orchids and other vascular epiphytes was found in zone 2 (Figure 3.A) or zone 3 (Figure 3.B). Only a small number of orchids grew in zone 2 of most trees, where many other vascular epiphytes were found. In contrast, a positive correlation between the number of epiphytic orchids and other vascular epiphytes was found in zone $4(\mathrm{r}=0.38, p=0.017$, Figure 3.C) and zone $5(r=0.55, p<0.001$, Figure 3.D).

Only a small number of orchids grew on the trunk (zone 2), which was dominated by other vascular epiphytes mainly by ferns (Figure 3.A). The low number of orchids attached to the trunk is probably because of the limited space as it covered with other vascular epiphytes and fewer horizontally inclined branches for orchid to colonize. Although epiphytes prefer to attach to trees with rough bark (Callaway et al. 2002), the rough bark of S. wallichii was revealed not to facilitate orchid colonization. According to Vergara-Torres et al. (2010) bark characteristics such as bark thickness, texture and peeling do not correlate with host quality for epiphytes. Vertical branchless trunks may not be suitable for epiphytic orchids, so despite their rough bark, the trunks of S. wallichii trees may be poor sites. Other factors that might limit epiphytic orchid grown on trunk would be the light availability. Crown suffers lighter compared with the trunk as crown always in higher position, therefore epiphytic orchids are more abundant at crown. On the other hand, other vascular epiphytic plants, mainly ferns, could grow on the trunk of S. wallichii trees. The reason for this would be that some fern species were able to survive in the shady trunk because they have highly sensitive photoreceptor (Schneider et al. 2004).

Ecological theory suggests that plants in stressful environments will show more positive than negative interactions (Bertness and Callaway 1994; Zotz 2016). Previous reports propose that the presence of non-vascular epiphytes, such as bryophytes, facilitates the establishment and survival of vascular epiphytes (Tremblay et al. 1998, Zotz and Volltrath 2003). In this study, there was a positive correlation between the abundance of orchids and other vascular epiphytes in zone 4 (Figure 3.C) and zone 5 (Figure 3.D).

Based on visual observations of the crown zones, orchids share habitat with mosses, lichens, and ferns and are often clumped in the same location. This would imply that there is no serious competition for space and nutrients between orchids and other vascular epiphytes in the middle and outer-crown of $S$. wallichii trees. In addition, other vascular epiphytes may act as 'islands' and facilitate the establishment of orchids, as bryophytes do. This kind of interaction has been recorded previously: ferns such as Drynaria or Platycerium established on bare bark, with increasing size and accumulation of organic material, these ferns provided a suitable substrate for the germination of epiphytic orchids like Cymbidium sp. (Wallace 1981; Zotz 2016).

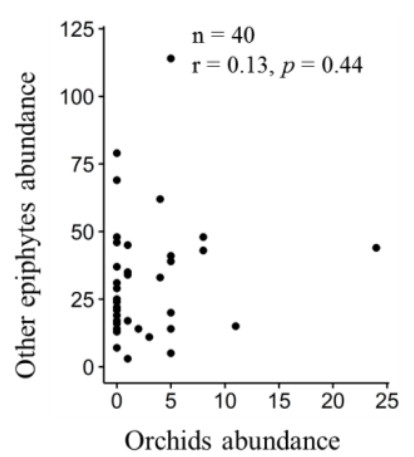

A

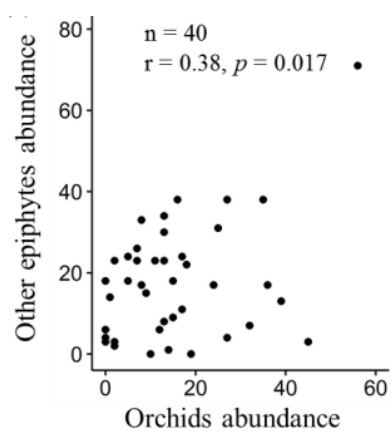

C

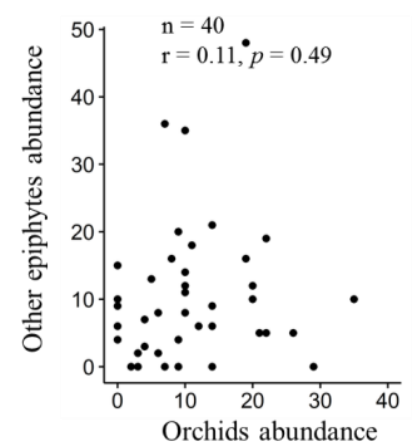

B

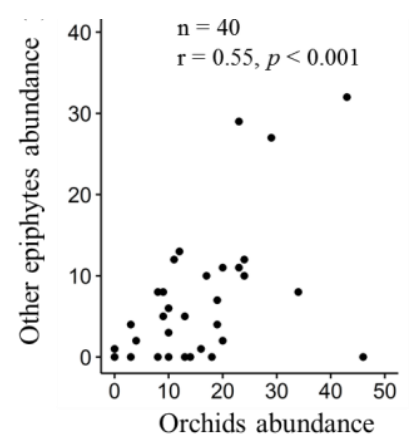

D
Figure 3. Relationship between the number of orchids and other vascular epiphytes: A. Trunk (zone 2), B. Inner crown (zone 3), C. Mid-crown (zone 4), D. Outer-crown (zone 5) of S. wallichii trees

The crowns of $S$. wallichii trees are essential for the epiphytic orchid community because they have numerous branches that orchids can easily attach to. Preservation of S. wallichii trees that are large and have numerous branches will assist in the conservation of a variety of epiphytic orchid species in tropical montane forests.

\section{ACKNOWLEDGEMENTS}

We wish to thank the Head of Perum Perhutani KPH Bandung Utara and BKPH Cisalak for support and permission to conduct this work. We also thank all those who assisted in this research.

\section{REFERENCES}

Awasthi OP, Sharma E, Palni LMS. 1995. Stem flow: a source of nutrients in some naturally growing epiphytic orchids of the Sikkim Himalaya. Ann Bot 75: 5-11. DOI: 10.1016/S0305-7364(05)80003$4 /$.

Bagheri A, Midi H. 2009. Robust estimations as a remedy for multicollinearity caused by multiple high leverage points. J Math Stat 5: 311-321. DOI: 10.3844/jmssp.2009.311.321.

BAKOSURTANAL. 2001. Peta rupa bumi digital Indonesia 1: 25000: lembar 1209-314 Lembang. Bakosurtanal. Bogor.

Benzing DH. 1990. Vascular epiphytes. General biology and related biota. Cambridge University Press. Cambridge. 
Bertness MD, Callaway R. 1994. Positive interactions in communities. Trends Ecol Evol 9: 191-193. DOI: 10.1038/nature00812.

Bloembergen S. 1952. A critical study in the complex-polymorphous genus Schima (Theaceae). Reindwardtia 2: 133-183. DOI: 10.14203/reinwardtia.v2i1.1019.

Bolker BM, Brooks ME, Clark CJ, Geange SW, Poulsen JR, Stevens MHH, White JS. 2009. Generalized linear mixed models: a practica guide for ecology and evolution. Trends Ecol Evol 24: 127-135. DOI: 10.1016/j.tree.2008.10.008

Callaway RM, Reinhart K, Moore GW, Pennings S. 2002. Epiphyte hos preferences and host traits: mechanism for species-specific interactions. Oecologia 132: 221-230. DOI: 10.1007/s00442-0020943-3.

Coble AP, Autio A, Cavaleri MA. 2014. Converging patterns of vertical variability in leaf morphology and nitrogen across seven Eucalyptus plantations in Brazil and Hawaii, USA. Trees 28: 1-15. DOI: 10.1007/s00468-013-0925-6.

Comber JB. 1990. Orchids of Java. The Bentham-moxon Trust, The Royal Botanic Gardens. Kew.

de la Rosa-Manzano E, Andrade JL, Zotz G, Reyes-García C. 2014 Epiphytic orchids in tropical dry forests of Yucatan, Mexico - Species occurrence, abundance and correlations with host tree characteristics and environmental conditions. Flora 209: 100-109. DOI: 10.1016/j.flora.2013.12.002.

Enloe HA, Graham RC, Sillet SC. 2006. Arboreal histosols in old-growth redwood forest canopies, Northern California. Soil Sci Soc Amer J 70: 408-418. DOI:10.2136/sssaj2004.0229.

Fardhani I, Kisanuki H, Parikesit. 2015. Diversity of Orchid Species in Mount Sanggarah, West Bandung. 22 ${ }^{\text {nd }}$ Tri-University International Joint Seminar Symposium, Jiangsu, China, 18-23 October 2015

Flores-Palacios A, García-Franco JG. 2001. Sampling method for vascular epiphytes: Their effectiveness in recording species richness and frequency. Selbyana 22: 181-191. http://www.jstor.org/stable/41760095.

Flores-Palacios A, García-Franco JG. 2006. The relationship between tree size and epiphyte species richness: Testing four different hypotheses. J Biogeogr 33: 323-330. DOI: 10.1111/j.1365-2699.2005.01382.x.

Garth RE. 1964. The ecology of Spanish moss (Tillandsia usneoides): its growth and distribution. Ecology 45: 470-481. DOI:10.2307/1936100.

Gower ST, Norman JM. 1991. Rapid estimation of leaf-area index in conifer and broad-leaf plantations. Ecology 72:1896-1900.

Gradstein SR, Nadkarni NM, Krömer T, Holz I, Noske N. 2003. A protocol for rapid and representative sampling of vascular and nonvascular epiphyte diversity of tropical rain forest. Selbyana 24: 105111.

Gravendeel B, Smithson A, Slik FJW, Schuiteman A. 2004. Epiphytism and pollinator specialization: drivers for orchid diversity? Phil Tran Royal Soc London B 359: 1523-1535. DOI: 10.1098/rstb.2004.1529.

Hietz P, Buchberger G, Winkler M. 2006. Effect of forest disturbance on abundance and distribution of epiphytic bromeliads and orchids Ecotropica 12: 103-112.

Hirata A, Kamijo T, Saito S. 2008. Host traits preferences and distribution of vascular epiphytes in a warm-temperate forest. Plant Ecol 201: 247-254. DOI: 10.1007/978-90-481-2795-5_19.

id.climate-data.org. 2018. Climate Lembang. en.climatedata.org/asia/indonesia/west-java/lembang-974703/

Ives AR. 2015. For testing the significance of regression coefficients, go ahead and log-transform count data. Methods Ecol Evol 6: 828-835. DOI: $10.1111 / 2041-210 X .12386$

Johansson D. 1974. Ecology of vascular epiphytes in West African rain forest. Acta Phytogeography Suecica 59: 1-136.

Krömer T, Kessler M, Gradstein SR. 2007. Vertical stratification of vascular epiphytes in submontane and montane forest of the Bolivian Andes: The importance of the understory. Plant Ecol 189: 261-278. DOI: $10.1007 / \mathrm{s} 11258-006-9182-8$.

Kwon Y, Larsen CPS, Lee M. 2018. Tree species richness predicted using a spatial environmental model including forest area and frost frequency, eastern USA. PLoS ONE 13: e0203881. DOI: 10.1371/journal.pone.0203881.

Lutz JA, Furniss TJ, Johnson DJ, Davies SJ, Allen D, Alonso A, et al. 2018. Global importance of large-diameter trees. Global Ecol Biogeogr 27: 849- 864. DOI: 10.1111/geb.12747.

Mansfield ER, Helms BP. 1982. Detecting Multicollinearity. The American Statistician 36: 158-160. DOI 10.1080/00031305.1982.10482818.
Marsusi M. 2001. A study of the epiphytic orchids in Jobolarangan Forest. Biodiversitas 2: 153-158. DOI: $10.13057 /$ biodiv/d020205. [Indonesian]

Mondragon D, Valverde T, Hernandez-Apolinar M. 2015. Population ecology of epiphytic angiosperms: a review. Trop Ecol 56: 01-39.

Muhamad D, Okubo S, Harashima K, Parikesit, Gunawan B, Takeuchi K. 2014. Living close to forests enhances people's perception of ecosystem services in a forest-agricultural landscape of West Java, Indonesia. Ecosyst Serv 8: 197-206. DOI: 10.1016/j.ecoser.2014.04.003.

Nadkarni NM, Matelson TJ. 1991. Fine litter dynamics within the tree canopy of a tropical cloud forest. Ecology 72: 2071-2082. DOI: $10.2307 / 1941560$

Nadkarni NM, Merwin MC, Nieder J. 2001. Forest canopies, plant diversity. Encyclopaedia of Biodiversity 3: 27-39.

Nieder J, Zotz G. 1998. Methods of analyzing the structure and dynamics of vascular epiphyte communities. Ecotropica 4: 33-39.

Nieder J, Prosperi J, Michaloud G. 2001. Epiphytes and their contribution to canopy diversity. Plant Ecol 153: 51-63. DOI: 10.1007/978-94017-3606-0_5.

O’Malley K. 2009. Patterns of abundance and diversity in epiphytic orchid on Parashorea malaanonan trees in Danum Valley, Sabah. Plymouth Stud Sci 2: 38-58

Orwa C, Mutua A, Kindt R, Jamnadass R, Anthony S. 2009. Agroforestree Database: a tree reference and selection guide version 4.0. http://old.worldagroforestry.org/treedb/AFTPDFS/Schima_wallichii.PDF

Puspitaningtyas D. 2007. Orchid Inventory and the Host in Meru Betiri National Park - East Java. Biodiversitas 8: 210-214. DOI: 10.13057/biodiv/d080309. [Indonesian]

R Development Core Team. 2016. R: A language and environment for statistical computing. $\mathrm{R}$ Foundation for Statistical Computing. Vienna, Austria. www.Rproject.org

RStudio Team. 2016. RStudio: Integrated development for R. RStudio, Inc. Boston, USA. www.rstudio.com

Rudolph D, Rauer G, Nieder J, Barthlott W. 1998. Distributional patterns of epiphytes in the canopy and phorophyte characteristics in a western Andean rain forest in Ecuador. Selbyana 19: 27-33.

Sanger JC, Kirkpatrick JB. 2015. Moss and vascular epiphyte distribution over host tree and elevation gradients in Australian subtropical rainforest. Austr J Bot 63: 696-704. DOI: 10.1071/BT15169.

Sanger JC, Kirkpatrick JB. 2017. Fine partitioning of epiphyte habitat within Johansson zones in tropical Australian rain forest trees. Biotropica 49: 27-34. DOI: 10.1111/btp.12351

Schneider H, Schuettpelz E, Pryer KM, Cranfill R, Magallón S, Lupia R. 2004. Ferns diversified in the shadow of angiosperms. Nature 428: 553-557

Setyawan AD. 2000. Epiphytic plants on stand of Schima wallichii (D.C.) Korth. at Mount Lawu. Biodiversitas 1: 14-20. DOI: 10.13057/biodiv/d010102. [Indonesian]

Sporn SG, Bos MM, Kessler M, Gradstein SR. 2009. Vertical distribution of epiphytic bryophytes in an Indonesian rainforest. Biodiv Conserv 19: 745. DOI: 10.1007/s10531-009-9731-2.

Taylor A, Burns K. 2015. Epiphyte community development throughout tree ontogeny: an island ontogeny framework. J Veg Sci 26: 902-910. DOI: $10.1111 /$ jvs.12289.

Ter Steege H, Cornellisen JHC. 1989. Distribution and ecology of vascular epiphytes in lowland rain forest of Guyana. Biotropica 2:

Tremblay RL, Zimmerman JK, Lebrón L, Bayman P, Sastre I, Axelrod F, Alers-García J. 1998. Host specificity and low reproductive success in the rare endemic Puerto Rican orchid Lepanthes caritensis. Biol Conserv 85: 297-304. DOI: 10.1016/S0006-3207(97)00163-8.

Tuyama S. 1989. Theaceae. In: Satake Y, Hara H, Watari S, Tominari T (eds.). Wild Flowers of Japan. Woody plants I. Heibunsha. Tokyo.

van Steenis CGGJ. 1972. The Mountain Flora of Java. Brill. Leiden.

Vergara-Torres CA, Pacheco-Alvarez MC, Flores-Palacios A. 2010. Host preference and host limitation of vascular epiphytes in a tropical dry forest of central Mexico. J Trop Ecol 26: 563-570. DOI: 10.1017/S0266467410000349.

Wagner K, Bogusch W, Zotz G. 2013. The role of the regeneration niche for the vertical stratification of vascular epiphytes. J Trop Ecol 29: 277-290. DOI: 10.1017/S0266467413000291.

Wallace BJ. 1981. The Australian vascular epiphytes: flora and ecology. [Dissertation]. University of New England, UK.

Yamada I. 1975. Forest ecological study of the mountain forest of Mt. Pangrango, West Java. South East Asian Stud 13: 402-426. DOI: 10.20495/tak.15.2_226. 
Zotz G. 2016. Plants on Plants - the Biology of Vascular Epiphytes. Springer, Berlin.

Zotz G, Hietz P. 2001. The physiological ecology of vascular epiphytes: current knowledge, open questions. J Exp Bot 52: 2067-2078. DOI: 10.1093/jexbot/52.364.2067.
Zotz G, Vollrath B. 2003. The epiphyte vegetation of the palm, Socratea exorrhiza - correlations with tree size, tree age, and bryophyte cover. J Trop Ecol 19: 81-90. DOI: 10.1017/S0266467403003092. 